\title{
A major step forward for sublingual immunotherapy: the quality of 5-grass pollen tablet is recognized also in Italy
}

This article was published in the following Dove Press journal:

Journal of Asthma and Allergy

6 March 2015

Number of times this article has been viewed

\section{Giorgio Ciprandi}

Medicine Department, IRCCSAzienda Ospedaliera Universitaria San Martino, Genoa, Italy
Correspondence: Giorgio Ciprandi Department of Medicine, IRCCS-Azienda Ospedaliera Universitaria San Martino, Viale Benedetto XV 6, I6I32 Genoa, Italy $\mathrm{Tel}+391035331820$

Fax +39 I0 3538664

Email gio.cip@libero.it

\section{Dear editor}

After a century of allergen immunotherapy (AIT), for the first time, the Italian Agency for Drugs (AIFA [Agenzia italiana per il farmaco]) has just approved the full reimbursement (A class) for an AIT product, such as the 5-grass pollen tablet with the indication for treating allergic rhinitis (AR).

On the other hand, AR represents a relevant health issue as the worldwide prevalence is approximately $20 \%{ }^{1}$ AR is sustained by an IgE-mediated inflammatory reaction that in turn induces typical symptom occurrence. Allergic inflammation is promoted by an allergen-specific defect of T-regulatory cells and a Th2 polarization. $^{2}$ This impaired immune response characterizes the two main peculiarities of allergic reaction: systemic IgE production and nasal eosinophil infiltrate. ${ }^{3}$ AR has also a significant social burden both in terms of high costs and individual complaints, mainly negatively affecting quality of life. AR treatment is traditionally based on drug prescription, such as antihistamines and topical corticosteroids. However, the main limit of drug therapy is that it is essentially symptomatic and its efficacy quickly stops after suspension. On the contrary, AIT is the unique causal therapy of AR as it is able of inducing a long-lasting immunological and clinical tolerance toward the causal allergen. ${ }^{4}$ The mechanism of action of AIT is based on restored T-regulatory function and re-direction of immune response to a physiological Th1-oriented pathway. ${ }^{5}$ AIT consists of administering increasing doses of the causal allergen extract able to reduce allergic symptoms. ${ }^{6}$ There is strengthened evidence that AIT is effective and safe as recognized by the meta-analysis approach. ${ }^{7}$ At present, sublingual immunotherapy is commonly prescribed for AR patients as effective and well tolerated.

The 5-grass pollen tablet according to a pre-co-seasonal course, has the indication for AR and/or conjunctivitis treatment in adult or pediatric (over 5 years) patients with severe symptoms as documented by two regulatory studies. ${ }^{8,9}$ AIFA's decision of full-reimbursement for the 5-grass pollen tablet has been based on the qualified requirements of this product: allergen panel composition, effectiveness, safety, standardization, adequate dosage, and pharmaco-economic impact. First, sublingual tablets are composed of 5-grass pollens, belonging to Pooideae family (Dactylis glomerata, Anthoxanthum odoratum, Lolium perenne, Poa pratensis, and Phleum pratense). This 5 -grass mixture is appropriate according to the production of pollen by the grasses as evidenced by phenological studies..$^{10}$ In fact, the approach by phenology demonstrated that the different grasses yield their pollen in dissimilar times of the season in 
a specific geographical area in Italy and that some grasses, such as $P$. pratense, produce their pollen in periods out of the pollen peaks in the atmosphere, when patients have no more intense symptoms. ${ }^{10}$ Of course, the presence of a given grass species is closely related to symptom appearance in grass allergic patients. Thus, the 5-grass mixture extract has optimal characteristics to cover the whole grass pollination period, so assuring a clinical effectiveness for a large population of grass pollen allergic patients. In addition, it has been reported that the 5-grass pollen mixture has ideal immunological capability of inducing immunization in AR patients, ${ }^{11,12}$ considering that 5-grass pollen tablet contains a large array of allergens naturally occurring in the atmosphere, that trigger allergic symptoms. An immunological study demonstrated that in children living in the Mediterranean area the 5-grass mixture is more alike to natural grass exposure than P. pratense extract alone. ${ }^{13}$ Another interesting issue is the molecular aspect, because among the grass species there is a lot of differences in the amino acid sequence of the allergens from the group 1 and 5, as confirmed by a study of Moingeon et $\mathrm{al}^{14}$ who highlighted by mass spectrometry the different three-dimensional structure of these allergens between the Pooideae that results in a large number of epitopes that are not shared among the various species. Indeed, the characteristics of 5-grass pollen tablet have a clinical relevance as the administration of the 5-grass-pollen mixture allows to obtain quick effectiveness. In this regard, a study using the "Vienna chamber" model showed that 5-grass pollen tablet significantly reduced allergic symptoms after 7-30 days. ${ }^{15}$ Moreover, an economic evaluation stated that 5-grass pollen tablet is a cost-effective treatment in patients with grass pollen-induced seasonal AR. ${ }^{16}$ Another intriguing aspect is that its cost-effectiveness increases with the severity of AR symptoms as evidenced by a recent analysis concerning the higher clinical efficacy of the 5-grass pollen tablet treatment in patients with more severe AR. ${ }^{17}$ These outcomes should be thoroughly taken into consideration in the management of AR patients. It is also of note that 5-grass pollen tablet is a drug listed as treating grass allergy with AIT by the Canadian Drug Expert Committee.

In conclusion, the AIFA decision about the full reimbursement of an AIT product for AR treatment has an outstanding importance for 5-grass pollen tablet, this fact provides a new consideration of AIT and paves the way to a new era in the centenary AIT history.

\section{Disclosure}

Giorgio Ciprandi is a scientific consultant for Stallergenes Italy, and has no other conflicts of interest to disclose.

\section{References}

1. Mims JW. Epidemiology of allergic rhinitis. Int Forum Allergy Rhinol. 2014;4 Suppl 2:S18-20

2. Wisniewski JA, Borish L. Novel cytokines and cytokine-producing T cells in allergic disorders. Allergy Asthma Proc. 2011;32(2):83-94.

3. Papazian D, Hansen S, Würtzen PA. Airway responses towards allergens-from the airway epithelium to T cells. Clin Exp Allergy. Epub 2014 Nov 14.

4. Petalas K, Durham SR. Allergen immunotherapy for allergic rhinitis. Rhinology. 2013;51(2):99-110.

5. Soyka MB, van de Veen W, Holzmann D, Akdis M, Akdis CA. Scientific foundations of allergen-specific immunotherapy for allergic disease. Chest. 2014;146(5):1347-1357.

6. Cox L. Sublingual immunotherapy for aeroallergens: status in the United States. Allergy Asthma Proc. 2014;35(1):34-42.

7. Wilson DR, Torres LI, Durham SR. Sublingual immunotherapy for allergic rhinitis. Cochrane Database Syst Rev. 2003;(2):CD002893.

8. Didier A. Malling HJ, Worm M, et al. Optimal dose, effectiveness, and safety of once-daily sublingual immunotherapy with a 5-grass pollen tablet for seasonal allergic rhinitis. J Allergy Clin Immunol. 2007;120(6):1338-1345.

9. Didier A, Worm M, Horak F et al. Sustained-3-year effectiveness of pre- and co-seasonal 5-grass pollen sublingual immunotherapy tablets in patients with grass pollen-induced rhinoconjunctivitis. J Allergy Clin Immunol. 2011;128(3):559-566.

10. Frenguelli G, Passalacqua G, Bonini S, et al. Bridging allergologic and botanical knowledge in seasonal allergy: a role for phenology. Ann Allergy Asthma Immunol. 2010;105(3):223-227.

11. Moingeon P, Hrabina M, Bergmann KC, et al. Specific immunotherapy for common grass pollen allergies: pertinence of a five grass pollen vaccine. Int Arch Allergy Immunol. 2008;146(4):338-342.

12. Manzotti G, Lombardi C. Allergen immunotherapy as a drug: the new deal of grass allergen tablets from clinical trials to current practice. Eur Ann Allergy Clin Immunol. 2013;45(2):34-42.

13. Marcucci F, Sensi L, Di Cara G, et al. Which allergen extract for grass pollen immunotherapy? An in vitro study. Immunol Invest. 2010;39(6):635-644

14. Chabre H, Gouyon B, Huet A, et al. Molecular variability of group 1 and 5 grass pollen allergens between Pooideae species: implications for immunotherapy. Clin Exp Allergy. 2010;40(3):505-519.

15. Horak F, Zieglmayer P, Zieglmayer R, et al. Early onset of action of a 5-grass-pollen 300-IR sublingual immunotherapy tablet evaluated in an allergen challenge chamber. J Allergy Clin Immunol. 2009;124(3):471-477.

16. Ruggeri M, Oradei M, Frati F, et al. Economic evaluation of 5-Grass pollen tablets versus placebo in the treatment of allergic rhinitis in adults. Clin Drug Investig. 2013;33(5):343-349.

17. Howarth P, Malling HJ, Molimard M, Devillier P. Analysis of allergen immunotherapy studies shows increased clinical efficacy in highly symptomatic patients. Allergy. 2012;67(3):321-327. 
Journal of Asthma and Allergy

\section{Publish your work in this journal}

The Journal of Asthma and Allergy is an international, peer-reviewed open-access journal publishing original research, reports, editorials and commentaries on the following topics: Asthma; Pulmonary physiology; Asthma related clinical health; Clinical immunology and the immunological basis of disease; Pharmacological interventions and

new therapies. Issues of patient safety and quality of care will also be considered. The manuscript management system is completely online and includes a very quick and fair peer-review system, which is all easy to use. Visit http://www.dovepress.com/testimonials.php to read real quotes from published authors.

Submit your manuscript here: http://www.dovepress.com/journal-of-asthma-and-allergy-journal 